\title{
Synthesis of quinoline/naphthalene-containing azaphenothiazines and their potent in vitro antioxidant properties
}

\author{
Małgorzata Jeleń · Eugenia I. Bavavea • Maria Pappa • \\ Angeliki P. Kourounakis • Beata Morak-Młodawska • \\ Krystian Pluta
}

Received: 11 June 2014/Accepted: 27 August 2014/Published online: 12 September 2014

(C) The Author(s) 2014. This article is published with open access at Springerlink.com

\begin{abstract}
New tetracyclic and pentacyclic azaphenothiazines containing one or two quinoline rings instead of benzene rings were obtained in the original reactions of isomeric diquinodithiins, dichlorodiquinolinyl sulfides, and disulfide with aromatic amines. The type of ring fusion in the azaphenothiazine system was concluded from the ${ }^{1} \mathrm{H}$ NMR spectra. The obtained azaphenothiazines were evaluated in vitro for their antioxidant activity on rat hepatic microsomal membranes for protection of non-enzymatic lipid peroxidation promoted by the $\mathrm{Fe}^{2+} /$ ascorbic acid redox system. Most compounds exhibited a very significant antioxidant activity with $\mathrm{IC}_{50}$ values between 1 and $23 \mu \mathrm{M}$. The degree of antioxidant activity depends on the lipophilicity and molecular size as well as the (non)substitution of the thiazine nitrogen atom and type of ring system fusion. It is the first time to our knowledge that azaphenothiazines are shown to exhibit such potent antioxidant activity.
\end{abstract}

Keywords Phenothiazine derivatives .

NH-azaphenothiazines · Quinonaphthothiazines ·

Diquinothiazines · Lipid peroxidation · Lipophilicity

M. Jeleń · B. Morak-Młodawska · K. Pluta $(\bowtie)$

Department of Organic Chemistry, School of Pharmacy with the

Division of Laboratory Medicine, The Medical University of

Silesia, Jagiellońska 4, 41-200 Sosnowiec, Poland

e-mail: pluta@sum.edu.pl

E. I. Bavavea - M. Pappa - A. P. Kourounakis

Department of Medicinal Chemistry, Faculty of Pharmacy,

University of Athens, 15771 Athens, Greece

\section{Introduction}

Phenothiazines are an important class of drugs exhibiting antipsychotic, antihistaminic, antitussive, and anti-emetic activities (Gupta and Kumar, 1988). The most significant modifications of the phenothiazine structure are the introduction of new pharmacophoric substituents at the thiazine nitrogen atom and the substitution of the benzene rings with other homoaromatic or heteroaromatic ones. Recently studied phenothiazines exhibit promising antibacterial, antifungal, anticancer, antiviral, anti-inflammatory, antimalarial, antifilarial, trypanocidal, anticonvulsant, analgesic, immunosuppressive, and multidrug resistance reversal properties (Aaron et al., 2009; Dasgupta et al., 2008; Motohashi et al., 2006; Pluta et al., 2011). In our study of new azaphenothiazines, we elaborated the synthesis of new types of phenothiazines containing the heterocyclic rings of pyridine or quinoline. Some of those azaphenothiazines exhibited promising immunosuppressive and anticancer activities against cell lines of ten types of human cancer in vitro: leukemia, non-small cell lung cancer, melanoma, as well as colon, CNS, ovarian, renal, prostate, breast, and skin cancer (Jeleń et al., 2013; Pluta et al., 2010; Zimecki et al., 2009).

Free radicals, generated in many redox processes, may induce oxidative damage of proteins, lipids, and DNA. They affect living cells and mediate the pathogenesis of many chronic diseases, such as atherosclerosis, Parkinson's and Alzheimer's diseases, stroke, and arthritis, acting by various mechanisms. A recent trend in the field of antioxidant development focuses on multipotent antioxidant agents that not only can prevent biological substrates from radical induced oxidative damage but also possess additional pharmacological properties (Zhang et al., 2006). The study of antioxidant activity among $\mathrm{N}$-heterocycles has 
attracted attention. One such heterocyclic structural scaffold is the 1,4-thiazine ring present in the multi-target phenothiazines. Therefore, recent reports on promising antioxidant compounds deal with classical and new phenothiazines (Asghar et al., 2012; Borges et al., 2010; Liu et al., 2009; Naik et al., 2012;) and their derivatives, benzothiazines (Matralis et al., 2011), and azaphenothiazines (Kumar et al., 2010; Morak-Młodawska et al., 2010).

Our previous work (Morak-Młodawska et al., 2010) revealed that tricyclic azaphenothiazines being dipyridothiazines have a variable degree of antioxidant activity depending on substitution at the thiazine nitrogen atom, with the unsubstituted compound being the most active. In this study, we obtained eleven tetracyclic and pentacyclic (linearly and angularly fused) azaphenothiazines containing one or two quinoline rings instead of the benzene rings and determined their antioxidant properties to find an influence of the number of rings, their type of fusion, and their substituents.

\section{Materials and methods}

\section{General techniques}

Melting points were determined in open capillary tubes on a Boetius melting point apparatus and were uncorrected. The ${ }^{1} \mathrm{H}$ NMR spectra were recorded on a Bruker Fourier 300 and a Bruker DRX spectrometer at $500 \mathrm{MHz}$ in $\mathrm{CDCl}_{3}$ and DMSO- $d_{6}$ with tetramethylsilane as the internal standard. The ${ }^{13} \mathrm{C}$ NMR spectra were recorded at $75 \mathrm{MHz}$. Electron impact (EI MS) mass spectra were run on a Finnigan MAT 95 spectrometer at $70 \mathrm{eV}$. The thin-layer chromatography was performed on aluminum oxide 60 $\mathrm{F}_{254}$ neutral (type $\mathrm{E}$, Merck 1.05581) with $\mathrm{CH}_{2} \mathrm{Cl}_{2}$ and on silica gel $60 \mathrm{~F}_{254}$ (Merck 1.05735) with $\mathrm{CHCl}_{3}-\mathrm{EtOH}(10: 1$ $\mathrm{v} / \mathrm{v})$ as eluents.

\section{Synthesis of substrates $\mathbf{1}, \mathbf{2}, \mathbf{7}, \mathbf{8}, \mathbf{1 0}$, and 11}

The substrates for the title compounds, i.e., diquinodithiins $\mathbf{1}, \mathbf{7}, \mathbf{1 0}$, sulfides $\mathbf{8}, \mathbf{1 1}$, and disulfide $\mathbf{2}$, were obtained as described previously (Nowak et al., 2002, 2003, 2007; Pluta, 1994).

\section{Quino[3,2-b]benzo[1,4]thiazines (3a-c)}

\section{From diquino-1,4-dithiin 1}

A mixture of diquino-1,4-dithiin $1(0.16 \mathrm{~g}, 0.5 \mathrm{mmol})$ and hydrochloride of aniline, or $p$-chloroaniline or $p$ methoxyaniline $(2.5 \mathrm{mmol})$ was finely powdered together and then heated on an oil bath at $200-205{ }^{\circ} \mathrm{C}$ for $4 \mathrm{~h}$ and after cooling water was added $(10 \mathrm{ml})$ and the insoluble solid was filtered off. The filtrate was alkalized with $5 \%$ aqueous sodium hydroxide to $\mathrm{pH} 10$, and the resulting solid was filtered off and washed with water. The combined solids were purified by column chromatography (silica gel, $\mathrm{CHCl}_{3}$ ) to give quinobenzothiazines $\mathbf{3 a}-\mathbf{c}$.

6H-Quinobenzothiazine (3a) $0.06 \mathrm{~g}$ (24\%), yellow, mp 169-170 ${ }^{\circ} \mathrm{C}\left(\mathrm{mp} 169-170{ }^{\circ} \mathrm{C}\right.$, Jeleń and Pluta, 2009). ${ }^{1} \mathrm{H}$ NMR $\left(\mathrm{CDCl}_{3}\right) \delta: 6.62(\mathrm{~m}, 1 \mathrm{H}, \mathrm{H}-7), 6.87(\mathrm{~m}, 1 \mathrm{H}, \mathrm{H}-9), 7$. 03 (m, 2H, H-8, H-10), 7.26 (t, 1H, H-2), 7.47 (m, 2H, H-1, $\mathrm{H}-3), 7.53$ (s, 1H, H-12), 7.56 (d, 1H, H-4). ${ }^{13} \mathrm{C} \mathrm{NMR}$ $\left(\mathrm{CDCl}_{3}\right) \quad \delta$ : $115.57(\mathrm{C}-7), 116.49$ and 116.69 (C-10a, C-11a), 122.95 (C-9), 124.19 (C-2), 125.86 (C-10), 126.04 and 126.45 (C-1, C-8), 126.56 (C-12a), 127.57 (C-4), 129. 52 (C-3), 131.69 (C-12), 138.45 (C-6a), 145.40 (C-4a), 150.98 (C-5a).

6H-9-Chloroquinobenzothiazine (3b) $0.08 \mathrm{~g} \quad$ (28\%), yellow, mp $224-225^{\circ} \mathrm{C}\left(\mathrm{mp} 224-225^{\circ} \mathrm{C}\right.$, Jelen and Pluta, 2009). ${ }^{1} \mathrm{H}$ NMR $\left(\mathrm{CDCl}_{3}\right) \delta: 6.63$ (d, 1H, H-7), 6.99 (s, $1 \mathrm{H}$, H-10), 7.01 (d, 1H, H-8), 7.33 (t, 1H, H-2), 7.51 (d, 1H, $\mathrm{H}-1), 7.52$ (t, 1H, H-3), 7.59 (d, 1H, H-4), $7.60(\mathrm{~s}, 1 \mathrm{H}$, $\mathrm{H}-12) .{ }^{13} \mathrm{C} \mathrm{NMR}\left(\mathrm{CDCl}_{3}\right) \delta: 115.80(\mathrm{C}-11 \mathrm{a}), 116.71(\mathrm{C}-7)$, 118.19 (C-10a), 124.84 and 124.91 (C-8, C-10), 125.65 (C2), 126.13 (C-12a), 126.61 (C-1), 127.59 (C-4), 128.56 (C9), 130.31 (C-3), 132.35 (C-12), 136.29 (C-6a), 143.81 (C4a), 150.04 (C-5a),

6H-9-Methoxyquinobenzothiazine (3c) $0.09 \mathrm{~g} \quad$ (32\%), orange, mp $159-160{ }^{\circ} \mathrm{C}$.

${ }^{1} \mathrm{H}$ NMR $\left(\mathrm{CDCl}_{3}\right) \delta 3.76\left(\mathrm{~s}, 3 \mathrm{H}, \mathrm{CH}_{3}\right), 6.54(\mathrm{~d}, 1 \mathrm{H}$, H-7), $6.63(\mathrm{~d}, 1 \mathrm{H}, \mathrm{H}-10), 6.76(\mathrm{~d}, 1 \mathrm{H}, \mathrm{H}-8), 7.29(\mathrm{t}, 1 \mathrm{H}$, $\mathrm{H}-2), 7.46(\mathrm{~d}, 1 \mathrm{H}, \mathrm{H}-1), 7.52$ (t, 1H, H-3), $7.55(\mathrm{~s}, 1 \mathrm{H}$, $\mathrm{H}-12), 7.57(\mathrm{~d}, 1 \mathrm{H}, \mathrm{H}-4),{ }^{13} \mathrm{C}$ NMR $\left(\mathrm{CDCl}_{3}\right) \delta: 111.59(\mathrm{C}-$ 10), 113.22 (C-8), 116.41 (C-11a), 116.82 (C-7), 117.39 (C-10a), 124.36 and 124.49 (C-1, C-2), 125.80 (C-12a), 126.55 (C-4), 130.10 (C-3), 130.60 (C-6a), 132.07 (C-12), 143.40 (C-4a), 150.36 (C-5a), 156.12 (C-9). EIMS m/z: 280 $\left(\mathrm{M}^{+}, \quad 100\right), 265 \quad\left(\mathrm{M}-\mathrm{CH}_{3}\right.$, 90). Anal. Calcd. for $\mathrm{C}_{16} \mathrm{H}_{12} \mathrm{~N}_{2} \mathrm{OS}$ : C, 68.55; H, 4.31; N, 9.99. Found: $\mathrm{C}, 68.45$; $\mathrm{H}, 4.36 ; \mathrm{N}, 9.82$.

\section{From 2,2'-dichloro-3,3'-diquinolinyl disulfide (2)}

A solution of disulfide $2(0.20 \mathrm{~g}, 0.5 \mathrm{mmol})$ and $p$-methoxyaniline $(0.25 \mathrm{~g}, 2 \mathrm{mmol})$ in monomethyl ether of diethylene glycol (MEDG) $(5 \mathrm{ml})$ was refluxed for $3 \mathrm{~h}$. After cooling, the solution was poured into water $(20 \mathrm{ml})$ and alkalized with $5 \%$ aqueous sodium hydroxide to $\mathrm{pH} 10$. The resulting solid was filtered off, washed with water, and purified by column chromatography (silica gel, $\mathrm{CHCl}_{3}$ ) to give $0.18 \mathrm{~g}(64 \%)$ of $6 H$-9-methoxyquinobenzothiazine (3c). 
Quino[3,2-b]naphtho[ $\left.1^{\prime}, 2^{\prime}-\mathrm{e}\right][1,4]$ thiazine (4)

Diquinodithiin 1 (0.16 g, $0.5 \mathrm{mmol})$ was finely powdered together with 1-naphthylamine hydrochloride $(0.45 \mathrm{~g}$, $2.5 \mathrm{mmol}$ ) on an oil bath at $200-205{ }^{\circ} \mathrm{C}$ for $4 \mathrm{~h}$. After cooling, the solution was poured into water $(10 \mathrm{ml})$ and alkalized with $5 \%$ aqueous sodium hydroxide to $\mathrm{pH} 10$. The resulting solid was filtered off, washed with water, and purified by column chromatography $\left(\mathrm{Al}_{2} \mathrm{O}_{3}, \mathrm{CHCl}_{3}\right)$ to give $0.08 \mathrm{~g}(27 \%)$ of $14 H$-quinonaphthothiazine (4), orange, mp $147-148{ }^{\circ} \mathrm{C}$.

${ }^{1} \mathrm{H}$ NMR $\left(\mathrm{CDCl}_{3}\right) \delta: 7.01(\mathrm{~d}, 1 \mathrm{H}, \mathrm{H}-6), 7.30(\mathrm{t}, 1 \mathrm{H}$, H-10), 7.47 (m, 4H, H-3, H-4, H-5, H-9), 7.52 (t, 1H, H-2), 7.56 (s, 1H, H-8), 7.60 (t, 1H, H-11), 7.64 (d, 1H, H-12), $7.75(\mathrm{~d}, 1 \mathrm{H}, \mathrm{H}-1) .{ }^{13} \mathrm{C} \mathrm{NMR}\left(\mathrm{CDCl}_{3}\right) \delta: 110.98(\mathrm{C}-6 \mathrm{a})$, 116.91 (C-7a), 118.43 (C-1), 121.89 (C-14b), 122.87 (C-6), 123.70 (C-5), 124.49 (C-10), 125.93, 126.45 and 126.83 (C-2, C-3, C-9), 126.90 (C-8a), 128.92 and 129.65 (C-4, C-12), 131.54 (C-11), 132.55 (C-4a), 133.04 (C-8), 135.07 (C-14a), 145.23 (C-12a), 150.98 (C-13a). EIMS m/z: 300 $\left(\mathrm{M}^{+}, 100\right), 268$ (M-S, 45). Anal. Calcd. for $\mathrm{C}_{19} \mathrm{H}_{12} \mathrm{~N}_{2} \mathrm{~S}: \mathrm{C}$, 75.97; H, 4.03; N, 9.33. Found: C, 75.82; H, 4.07; N, 9.21.

Quino[3,2-b]naphtho[2', $1^{\prime}$-e][1,4]thiazine (5)

Diquinodithiin $1(0.16 \mathrm{~g}, 0.5 \mathrm{mmol})$ was finely powdered together with 2-naphthylamine hydrochloride $(0.45 \mathrm{~g}$, $2.5 \mathrm{mmol}$ ) on an oil bath at $200-205^{\circ} \mathrm{C}$ for $4 \mathrm{~h}$. After cooling, the solution was poured into water $(10 \mathrm{ml})$ and alkalized with $5 \%$ aqueous sodium hydroxide to $\mathrm{pH} 10$. The resulting solid was filtered off, washed with water, and purified by column chromatography $\left(\mathrm{Al}_{2} \mathrm{O}_{3}, \mathrm{CHCl}_{3}\right)$ to give $0.12 \mathrm{~g}(40 \%)$ of $7 \mathrm{H}$-quinonaphthothiazine (5), greenish, mp 244-245 ${ }^{\circ} \mathrm{C}$.

${ }^{1} \mathrm{H} \mathrm{NMR}\left(\mathrm{CDCl}_{3}\right) \delta: 7.06(\mathrm{~d}, 1 \mathrm{H}, \mathrm{H}-6), 7.37(\mathrm{t}, 1 \mathrm{H}$, H-11), 7.47 (t, 1H, H-3), 7,57 (m, 3H, H-2, H-10, H-12), 7.65 (d, 1H, H-5), 7.66 (d, 1H, H-4), 7.72 (s, 1H, H-13), $7.80(\mathrm{~m}, 2 \mathrm{H}, \mathrm{H}-9, \mathrm{H}-1) .{ }^{13} \mathrm{C} \mathrm{NMR}\left(\mathrm{CDCl}_{3}\right) \delta: 107.94(\mathrm{C}-$ 14a), 115.77 (C-13a), 116.04 (C-6), 121.32 (C-1), 123.33, 123.66 and 123.89 (C-3, C-9, C-11), 125.23 (C-12a), 125.62 (C-2), 126.36, 126.99 and 127.56 (C-4, C-5, C-12), 128.73 (C-4a), 129.22 (C-10), 129.62 (C-14b), 131.51 (C13), 133.54 (C-6a), 142.13 (C-8a), 149.64 (C-7a). EIMS m/ z: $300\left(\mathrm{M}^{+}\right.$, 100), 268 (M-S, 50). Anal. Calcd. for $\mathrm{C}_{19} \mathrm{H}_{12} \mathrm{~N}_{2} \mathrm{~S}$ : C, 75.97; H, 4.03; N, 9.33. Found: C, 75.88; H, $4.05 ; \mathrm{N}, 9.19$.

\section{Diquino[3,2-b; $\left.6^{\prime}, 5^{\prime}-\mathrm{e}\right][1,4]$ thiazine $(6)$}

Diquinodithiin 1 (0.16 g, $0.5 \mathrm{mmol})$ was finely powdered together with 6-aminoquinoline hydrochloride $(0.46 \mathrm{~g}$, $2.5 \mathrm{mmol}$ ) on an oil bath at $200-205{ }^{\circ} \mathrm{C}$ for $4 \mathrm{~h}$. After cooling, the solution was poured into water $(10 \mathrm{ml})$ and alkalized with $5 \%$ aqueous sodium hydroxide to $\mathrm{pH} 10$. The resulting solid was filtered off, washed with water, and purified by column chromatography $\left(\mathrm{Al}_{2} \mathrm{O}_{3}, \mathrm{CHCl}_{3}\right)$ to give $0.10 \mathrm{~g}(33 \%)$ of $7 \mathrm{H}$-diquinothiazine (6), brown, mp 260-261 ${ }^{\circ} \mathrm{C}$.

${ }^{1} \mathrm{H} \mathrm{NMR}\left(\mathrm{CDCl}_{3}\right) \delta: 7.44(\mathrm{t}, 1 \mathrm{H}, \mathrm{H}-11), 7.49(\mathrm{~d}, 1 \mathrm{H}, \mathrm{H}-6)$, 7.57 (m, 2H, H-2, H-12), 7.64 (t, 1H, H-10), 7.70 (d, 1H, H-9), 7.75 (s, 1H, H-13), 8.10 (d, 1H, H-5), 8.19 (d, 1H, H-1), $8.90(\mathrm{~d}, 1 \mathrm{H}, \mathrm{H}-3) .{ }^{13} \mathrm{C} \mathrm{NMR}\left(\mathrm{CDCl}_{3}\right) \delta: 107.62(\mathrm{C}-14 \mathrm{a})$, 114.59 (C-13a), 119.33 (C-6), 120.76 (C-2), 124.05 (C-11), 124.37 and 125.45 (C-12a, C-14b), 125.65 (C-12), 128.27, 129.24, 129.62 and 129.64 (C-1, C-5, C-9, C-10), 131.80 (C13), 134.54 (C-6a), 144.53 (C-7a), 147.55 (C-3), 149.49 and 149.55 (C-4a, C-8a). EIMS m/z: $301\left(\mathrm{M}^{+}, 100\right), 269$ (M-S, 45). Anal. Calcd. for $\mathrm{C}_{18} \mathrm{H}_{11} \mathrm{~N}_{3} \mathrm{~S}: \mathrm{C}, 71.74 ; \mathrm{H}, 3.68 ; \mathrm{N}, 13.94$. Found: C, 71.59; H, 3.71; N, 13.72.

Diquino[3,2-b;2' $2^{\prime}$-e][1,4]thiazines (9)

\section{H-Diquinothiazine $9 a$}

This compound was obtained in the reaction of diquinodithiin 7 with acetamide (Nowak et al., 2007), orange, $\mathrm{mp}>300{ }^{\circ} \mathrm{C}\left(\mathrm{mp}>300{ }^{\circ} \mathrm{C}\right.$, Nowak et al., 2007). ${ }^{1} \mathrm{H}$ NMR $\left(\mathrm{CDCl}_{3}\right) \delta: 7.42(\mathrm{t}, 2 \mathrm{H}, \mathrm{H}-2, \mathrm{H}-10), 7.55(\mathrm{~d}, 2 \mathrm{H}$, $\mathrm{H}-1, \mathrm{H}-11), 7.62$ (t, 2H, H-3, H-9), 7.72 (s, 2H, H-12, $\mathrm{H}-14), 7.86$ (d, 2H, H-4, H-8). ${ }^{13} \mathrm{C}$ NMR (DMSO- $\left.d_{6}\right) \delta$ : 124.83 (C-12a, C-13a), 127.29 (C-2, C-10), 128.00 (C-11a, C-14a), 128.16 and 128.28 (C-1, C-11 and C-4, C-8), 131.29 (C-3, C-9), 135.26 (C-12, C-14), 146.58 (C-4a, C-7a), 156.22 (C-5a, C-6a).

\section{6-(p-Fluorophenyl)diquinothiazine $(\mathbf{9 b})$}

From diquinodithiin 7 Diquinodithiin 7 (0.16 g, 0. $5 \mathrm{mmol}$ ) was finely powdered together with $p$-fluoroaniline hydrochloride $(0.37 \mathrm{~g}, 2.5 \mathrm{mmol})$, and the mixture was heated on an oil bath at $200-205^{\circ} \mathrm{C}$ for $3 \mathrm{~h}$. After cooling, water $(10 \mathrm{ml})$ was added to the reaction mixture and the resulting solid was filtered off, washed with water, airdried, and purified by column chromatography $\left(\mathrm{Al}_{2} \mathrm{O}_{3}\right.$, $\left.\mathrm{CH}_{2} \mathrm{Cl}_{2}\right)$ to give $0.14 \mathrm{~g}(35 \%)$ of 6 -( $p$-fluorophenyl)diquinothiazine (9b), yellow, mp $248-249{ }^{\circ} \mathrm{C}$.

From 2,2'-dichloro-3,3'-diquinolinyl sulfide 8 A solution of sulfide $8(0.18 \mathrm{~g}, 0.5 \mathrm{mmol})$ and $p$-fluoroaniline $(0.17 \mathrm{~g}$, $1.5 \mathrm{mmol})$ in MEDG $(5 \mathrm{ml})$ was refluxed for $3 \mathrm{~h}$. After cooling, the solution was poured into water $(20 \mathrm{ml})$ and alkalized with $5 \%$ aqueous sodium hydroxide to $\mathrm{pH}=10$. The resulting solid was filtered off, washed with water, and purified by column chromatography $\left(\mathrm{Al}_{2} \mathrm{O}_{3}, \mathrm{CH}_{2} \mathrm{Cl}_{2}\right)$ to give $0.16 \mathrm{~g}(81 \%)$ 6-(p-fluorophenyldiquinothiazine (9b), yellow, mp $248-249^{\circ} \mathrm{C}$. 
${ }^{1} \mathrm{H}$ NMR $\left(\mathrm{CDCl}_{3}\right) \delta: 7.31\left(\mathrm{~m}, 4 \mathrm{H}, \mathrm{H}-2, \mathrm{H}-10, \mathrm{C}_{6} \mathrm{H}_{2}\right)$, 7.47 (m, 4H, H-3, H-9, $\mathrm{C}_{6} \mathrm{H}_{2}$ ), 7.56 (d, 2H, H-1, H-11), 7.67 (d, 2H, H-4, H-8), 7.83 (s, 2H, H-12, H-14). ${ }^{13} \mathrm{C}$ NMR $\left(\mathrm{CDCl}_{3}\right) \delta$ : $115.85\left(\mathrm{~J}=22.6 \mathrm{~Hz}, m-\mathrm{C}\right.$ of $\left.\mathrm{C}_{6} \mathrm{H}_{4} \mathrm{~F}\right), 115.98$ (C-12a, C-13a), 125.16 (C-2, C-10), 125.78 (C-11a, C-14a), 125.96 (C-1, C-11), 128.07 (C-4, C-8), 129.37 (C3, C-9), 132.07 (C-12, C-14), $132.40(J=7.5 \mathrm{~Hz}, o-\mathrm{C}$ of $\left.\mathrm{C}_{6} \mathrm{H}_{4} \mathrm{~F}\right), 135.59\left(\mathrm{~J}=2.5 \mathrm{~Hz}\right.$, ipso-C of $\left.\mathrm{C}_{6} \mathrm{H}_{4} \mathrm{~F}\right), 145.13(\mathrm{C}-$ 4a, C-7a), 150.98 (C-5a, C-6a), 161.83 ( $J=244.6$ Hz, $p-\mathrm{C}$ of $\left.\mathrm{C}_{6} \mathrm{H}_{4} \mathrm{~F}\right)$.

EIMS m/z: $395\left(\mathrm{M}^{+}, 75\right), 394$ (M-1, 100), 363 (M-S, 5). Anal. Calcd. for $\mathrm{C}_{24} \mathrm{H}_{14} \mathrm{FN}_{3} \mathrm{~S}$ : C, 72.89; H, 3.57; N, 10.63. Found: C, 72.80; H, 3.55; N, 10.41 .

Diquino[3,4-b; $4^{\prime}, 3^{\prime}$-e] $[1,4]$ thiazines $(\mathbf{1 2 a} \mathbf{a}-\mathbf{c})$

6H-Diquinothiazine (12a) and 6-methyldiquinothiazine (12b) were obtained from the reaction of sulfide $\mathbf{1 1}$ with ammonia and methylamine in hot phenol (Pluta, 1997).

\section{H-Diquinothiazine (12a)}

Beige, mp 200-201 ${ }^{\circ} \mathrm{C}$ (mp 200-201 ${ }^{\circ} \mathrm{C}$, Pluta, 1997). ${ }^{1} \mathrm{H}$ NMR $\left(\mathrm{CDCl}_{3}\right) \delta: 7.64$ (t, 2H, H-2, H-12), $7.71(\mathrm{t}, 2 \mathrm{H}, \mathrm{H}-3$, H-11), 7.81 (d, 2H, H-4, H-10), 8.04 (d, 2H, H-1, H-13), 8.40 (s, 2H, H-6, H-8). ${ }^{13} \mathrm{C}$ NMR $\left(\mathrm{CDCl}_{3}\right) \delta: 109.10$ (C-6a, C-7a), 117.18 (C-13a, C-14b), 117.41 (C-1, C-13), 127.25 (C-2, C-12), 129.49 (C-3, C-11), 130.78 (C-4, C-10), 142.21 (C-4a, C-9a), 147.94 (C-6, C-8), 148.07 (C-13b, C-14a).

\section{6-Methyldiquinothiazine (12b)}

Yellow, mp 156-157 ${ }^{\circ} \mathrm{C}\left(\mathrm{mp} 156-157{ }^{\circ} \mathrm{C}\right.$, Pluta, 1997). ${ }^{1} \mathrm{H}$ $\mathrm{NMR}\left(\mathrm{CDCl}_{3}\right) \delta: 3.54\left(\mathrm{~s}, 3 \mathrm{H}, \mathrm{CH}_{3}\right), 7.66(\mathrm{t}, 2 \mathrm{H}, \mathrm{H}-2$, H-12), 7.72 (t, 2H, H-3, H-11), 8.11 (d, 2H, H-4, H-10), 8.34 (d, 2H, H-1, H-13), 8.66 (s, 2H, H-6, H-8). ${ }^{13} \mathrm{C} \mathrm{NMR}$ $\left(\mathrm{CDCl}_{3}\right) \delta: 43.63\left(\mathrm{CH}_{3}\right), 122.09(\mathrm{C}-1, \mathrm{C}-13), 124.17$ and 124.42 (C-6a, C-7a and C-13a, C-14b), 127.46 (C-2, C-12), 129.44 (C-3, C-11), 130.11 (C-4, C-10), 148.33 (C-6, C-8), 148.76 and 148.85 (C-4a, C-9a and C-13b, C-14a).

14-(p-Fluorophenyl)diquinothiazine (12c)

\section{From diquinodithiin 10}

Diquinodithiin 10 (0.16 g, $0.5 \mathrm{mmol})$ was finely powdered together with $p$-fluoroaniline hydrochloride $(0.37 \mathrm{~g}$, $2.5 \mathrm{mmol}$ ), and the mixture was heated on an oil bath at 200-205 ${ }^{\circ} \mathrm{C}$ for $3 \mathrm{~h}$. After cooling, water $(10 \mathrm{ml})$ was added to the reaction mixture and the resulting solid was filtered off, washed with water, air-dried, and purified by column chromatography $\left(\mathrm{Al}_{2} \mathrm{O}_{3}, \mathrm{CH}_{2} \mathrm{Cl}_{2}\right)$ to give $0.12 \mathrm{~g}$
(30\%) of 14-(p-fluorophenyl)diquinothiazine (12c), beige, mp $315-316^{\circ} \mathrm{C}$.

\section{From 4,4'-dichloro-3,3'-diquinolinyl sulfide (11)}

A solution of sulfide $11(0.18 \mathrm{~g}, 0.5 \mathrm{mmol})$ and $p$-fluoroaniline $(0.17 \mathrm{~g}, 1.5 \mathrm{mmol})$ in MEDG $(5 \mathrm{~mL})$ was refluxed for $3 \mathrm{~h}$. After cooling, the solution was poured into water $(20 \mathrm{ml})$ and alkalized with $5 \%$ aqueous sodium hydroxide to $\mathrm{pH}$ 10. The resulting solid was filtered off, washed with water and purified by column chromatography $\left(\mathrm{Al}_{2} \mathrm{O}_{3}\right.$, $\left.\mathrm{CHCl}_{3}\right)$ to give $0.17 \mathrm{~g}(86 \%)$ of 14 -( $p$-fluorophenyl)diquinothiazine $(\mathbf{1 2 c})$, beige, $\mathrm{mp} 315-316^{\circ} \mathrm{C}$.

${ }^{1} \mathrm{H}$ NMR $\left(\mathrm{CDCl}_{3}\right) \delta: 6.43\left(\mathrm{dd}, 2 \mathrm{H}, \mathrm{C}_{6} \mathrm{H}_{2}\right), 6.77(\mathrm{~m}, 2 \mathrm{H}$, $\left.\mathrm{C}_{6} \mathrm{H}_{2}\right), 7.75$ (t, 2H, H-2, H-12), 7.85 (t, 2H, H-3, H-11), 8.34 (d, 2H, H-4, H-10), 8.39 (d, 2H, H-1, H-13), 9,06 (s, $2 \mathrm{H}, \mathrm{H}-6, \mathrm{H}-8) .{ }^{13} \mathrm{C} \mathrm{NMR}\left(\mathrm{CDCl}_{3}\right) \delta: 115.75(\mathrm{~J}=22.5 \mathrm{~Hz}$, $m-\mathrm{C}$ of $\left.\mathrm{C}_{6} \mathrm{H}_{4} \mathrm{~F}\right), 116.30\left(\mathrm{~J}=7.5 \mathrm{~Hz}, o-\mathrm{C}\right.$ of $\left.\mathrm{C}_{6} \mathrm{H}_{4} \mathrm{~F}\right)$, 122.87 (C-1, C-13), 126.82 (C-13a, C-14b), 128.51 (C-2, C-12), 129.89 (C-6a, C-7a), 130.13 (C-3, C-11), 130.25 (C4, C-10), $140.57\left(\mathrm{~J}=2.5 \mathrm{~Hz}\right.$, ipso-C of $\left.\mathrm{C}_{6} \mathrm{H}_{4} \mathrm{~F}\right), 145.54$ (C-13b, C-14a), 147.98 (C-4a, C-9a), 149.49 (C-6, C-8), $158.07\left(\mathrm{~J}=238.5 \mathrm{~Hz}, p-\mathrm{C}\right.$ of $\left.\mathrm{C}_{6} \mathrm{H}_{4} \mathrm{~F}\right)$. EIMS $\mathrm{m} / z: 395$ $\left(\mathrm{M}^{+}, 100\right), 363(\mathrm{M}-\mathrm{S}, 20), 300\left(\mathrm{M}-\mathrm{C}_{6} \mathrm{H}_{4} \mathrm{~F}, 17\right)$. Anal. Calcd. for $\mathrm{C}_{24} \mathrm{H}_{14} \mathrm{FN}_{3} \mathrm{~S}$ : C, 72.89; H, 3.57; N, 10.63. Found: C, 72.77 ; H, 3.59; N, 10.46 .

In vitro lipid peroxidation

Heat-inactivated hepatic microsomes from untreated rats were prepared as described (Rekka et al., 1989). The incubation mixture contained microsomal fraction (corresponding to $2.5 \mathrm{mg}$ of hepatic protein per $\mathrm{ml}$ or $4 \mathrm{mM}$ fatty acid residues), ascorbic acid $(0.2 \mathrm{mM})$ in Tris- $\mathrm{HCl} / \mathrm{KCl}$ buffer $(50 \mathrm{mM} / 150 \mathrm{mM}, \mathrm{pH} 7.4)$, and the studied compounds $(50-1 \mu \mathrm{M})$ dissolved in DMSO. The reaction was initiated by addition of a freshly prepared $\mathrm{FeSO}_{4}$ solution $(10 \mu \mathrm{M})$, and the mixture was incubated at $37^{\circ} \mathrm{C}$ for 45 min. Lipid peroxidation of aliquots was assessed spectrophotometrically (535 against $600 \mathrm{~nm}$ ) as TBAR. Both compounds and solvents were found not to interfere with the assay. Each assay was performed in duplicate, and $\mathrm{IC}_{50}$ values represent the mean concentration of compounds that inhibit the peroxidation of control microsomes by $50 \%$ after $45 \mathrm{~min}$ of incubation. All standard errors are within $10 \%$ of the respective reported values.

Calculation of lipophilicity, molecular mass, surface area, and molecular volume

Lipophilicity (as cLogP), molecular mass (M), surface area $(\mathrm{S})$, and molecular volume $\left(\mathrm{V}_{\mathrm{M}}\right)$ were calculated using $\mathrm{CS}$ 


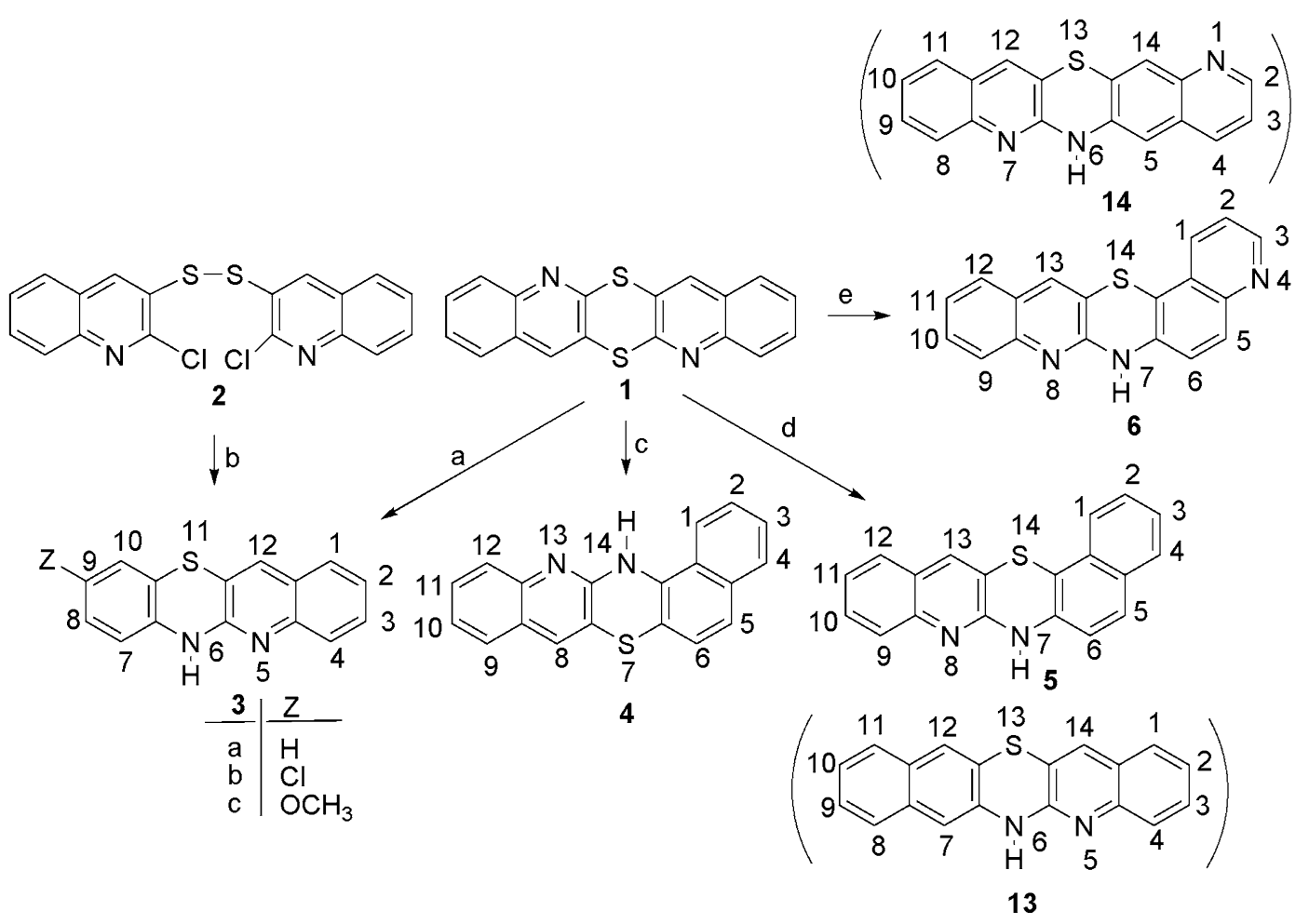

Scheme 1 Reactans: a $\mathrm{C}_{6} \mathrm{H}_{5} \mathrm{NH}_{2} \cdot \mathrm{HCl}\left(p-\mathrm{ClC}_{6} \mathrm{H}_{4} \mathrm{NH}_{2} \cdot \mathrm{HCl}, p-\mathrm{CH}_{3} \mathrm{OC}_{6} \mathrm{H}_{4} \mathrm{NH}_{2} \cdot \mathrm{HCl}\right), 200-205{ }^{\circ} \mathrm{C}, 4 \mathrm{~h} ; \mathbf{b} p-\mathrm{CH}_{3} \mathrm{OC}{ }_{6} \mathrm{H}_{4} \mathrm{NH}_{2}, \mathrm{MEDG}, \mathrm{reflux}, 3$ h; c 1-naphthylamine $\cdot \mathrm{HCl}, 200-205{ }^{\circ} \mathrm{C}, 4 \mathrm{~h}$; d 2-naphthylamine $\cdot \mathrm{HCl}, 200-205{ }^{\circ} \mathrm{C}, 4 \mathrm{~h}$; e 6-aminoquinoline $\cdot \mathrm{HCl}, 200-205{ }^{\circ} \mathrm{C}, 4 \mathrm{~h}$

Chem 3D Ultra 7.0 (CambridgeSoft) and Spartan'04 (Wavefunction, Inc. Irvine, CA).

\section{Results and discussion}

Synthesis

The synthesis of the title azaphenothiazines was based on the reactions of isomeric diquinodithiins, dichlorodiquinolinyl sulfides, and disulfide with amines, ammonia, and acetamide. The fusion reactions of linearly condensed diquinodithiin 1 with hydrochlorides of aniline and its $p$ substituted derivatives such as $p$-chloroaniline and $p$ methoxyaniline led to tetracyclic 9-substituted $6 H$-quinobenzothiazines 3a-c (Scheme 1). 9-Methoxy-6H-quinobenzothiazine 3c was obtained in better yield in the reaction of 2,2'-dichloro-3,3'-diquinolinyl disulfide 2 with $p$-methoxyaniline in monomethyl ether of diethylene glycol. The similar reaction of diquinodithiin $\mathbf{1}$ with hydrochlorides of 1-naphthylamine, 2-naphthylamine, and 6-aminoquinoline gave pentacyclic $7 H$-quinonaphthothiazine 4, 14H-quinonaphthothiazine 5, and $7 H$-diquinothiazine 6. The reaction of isomeric diquinodithiin 7 with acetamide and $p$-fluoroaniline hydrochloride gave linearly condensed pentacyclic $6 H$-diquinothiazines 9a and $6-(p$ - fluorophenyl)diquinothiazine 9b (Scheme 2). Analogous reaction of another isomeric diquinodithiin $\mathbf{1 0}$ with $p$ fluoroaniline hydrochloride led to angularly condensed diquinothiazine 12c. Better yields of the fluoroaniline products $9 \mathrm{~b}$ and $\mathbf{1 2 c}$ were achieved when $\mathrm{x}, \mathrm{x}$ '-dichloro3,3'-diquinolinyl sulfides $\mathbf{8}$ and $\mathbf{1 1}$ ( $x=2$ and 4) were used. Sulfide $\mathbf{1 1}$ reacted also with ammonia or methylamine in hot phenol to give diquinothiazines $\mathbf{1 2 a}, \mathbf{b}$.

The described syntheses were monitored by TLC analysis. All chromatograms of new compounds showed characteristic for azaphenothiazines (Jeleń et al., 2011) color changing during irradiation with UV light from blue to yellow $(\mathbf{4}, \mathbf{9 b})$, from yellow to green $(5,6)$, from orange to yellow (12c), and from yellow to orange (7c).

\section{Structure}

It is well known that the synthesis of phenothiazines can proceed via the Smiles rearrangement of the S-N type of the appropriate sulfide (Pluta et al., 2009). The identification of the product structures was based on the spectroscopic ${ }^{1} \mathrm{H}$ NMR and MS analysis. In the case of the reactions of sulfides 7 and 11, the products 9 and 12 possessed the $\mathrm{C}_{2 \mathrm{v}}$ symmetry (the left part was a mirror image of the right one) what excluded the stage of rearrangement. The reactions of diquinodithiin $\mathbf{1}$ and disulfide $\mathbf{2}$ with 


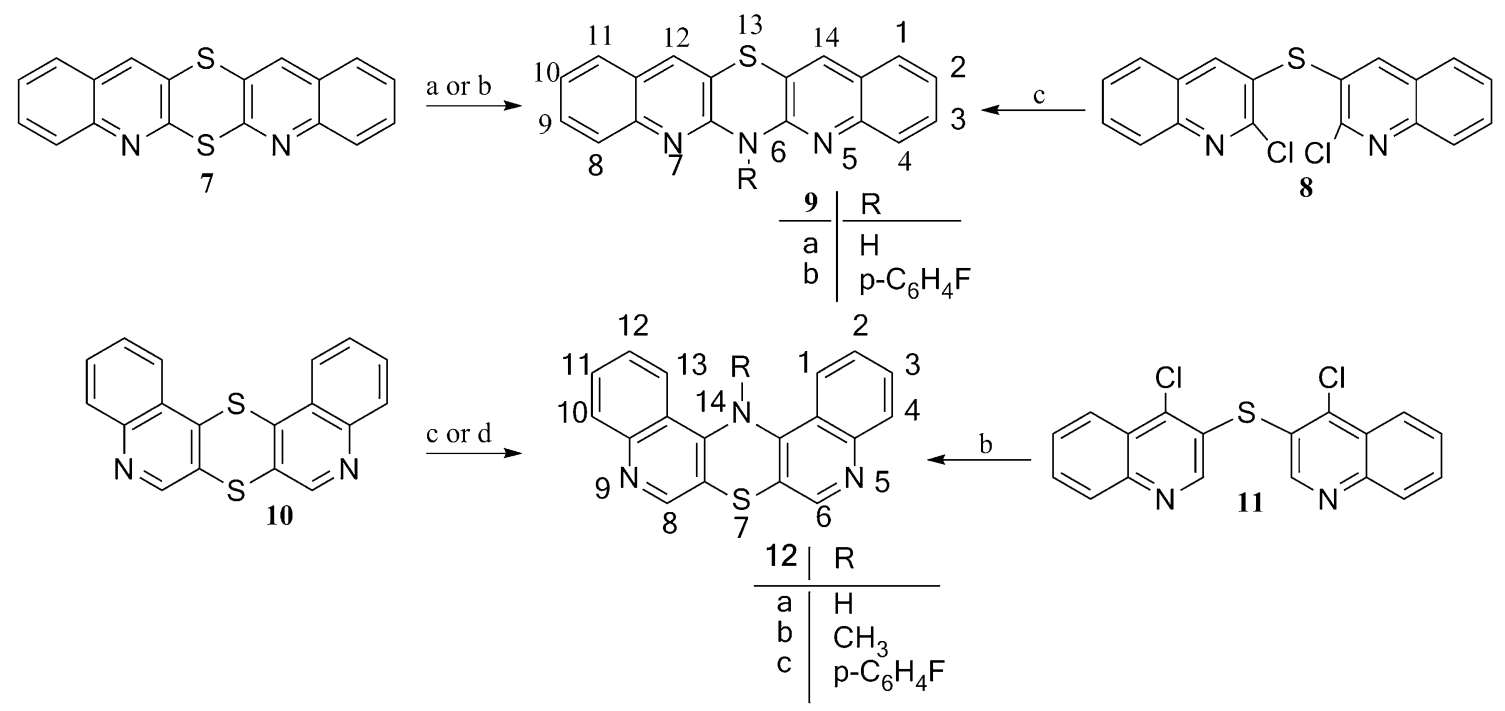

Scheme 2 Reactans: a $\mathrm{CH}_{3} \mathrm{CONH}_{2}, \mathrm{~K}_{2} \mathrm{CO}_{3}, 180{ }^{\circ} \mathrm{C}, 0.5 \mathrm{~h}$; b $p$ F- $\left.\mathrm{C}_{6} \mathrm{H}_{4} \mathrm{NH}_{2} \cdot \mathrm{HCl}\right), 200-205{ }^{\circ} \mathrm{C}, 3 \mathrm{~h} ; \mathbf{c} p-\mathrm{FC}_{6} \mathrm{H}_{4} \mathrm{NH}_{2}, \mathrm{MEDG}$ reflux, 3 h; d NH 3 $\left(\mathrm{CH}_{3} \mathrm{NH}_{2}\right)$, phenol, $180{ }^{\circ} \mathrm{C}, 1 \mathrm{~h}$

anilines proceeded similarly without the stage of rearrangement to give tetracyclic quinobenzothiazines 3ac (Jeleń and Pluta, 2009). The reaction with 1-naphthylamine gave pentacyclic quinonaphthothiazine 4 . On the contrary, the reactions with 2-naphthylamine and 6-aminoquinoline were more complex as there were two possibilities of the thiazine ring formation. The ${ }^{1} \mathrm{H}$ NMR analysis of the reaction products pointed at compounds $\mathbf{5}$ and $\mathbf{6}$ excluding compounds $\mathbf{1 3}$ and $\mathbf{1 4}$, as evidenced from coupling constants; the H-5 and H-6 protons in compounds 5 and $\mathbf{6}$ showed a coupling constant $J_{\text {ortho, }}$, whereas analogous protons in compounds 13 and $\mathbf{1 4}(\mathrm{H}-7 / \mathrm{H}-12$ and $\mathrm{H}-5 /$ $\mathrm{H}-14$, respectively) would have shown a coupling constant $J_{\text {para }}$, which is very small (i.e., $J_{1,4}=0.6-0.8 \mathrm{~Hz}$ in naphthalene (Hamm and von Philipsborn, 1971; Lucchini and Wells, 1976) and $J_{5,8}=0.5-0.8 \mathrm{~Hz}$ in quinoline (Hamm and von Philipsborn, 1971; Jones, 1977). We did not observe such small values of coupling constants in the reaction products 5 and $\mathbf{6}$.

\section{Antioxidant activity}

The effect of the new derivatives on non-enzymatic lipid peroxidation of rat hepatic microsomal membrane lipids was investigated in vitro. Most of the studied derivatives demonstrated significant antioxidant activity, with $\mathrm{IC}_{50}$ values between 1 and $23 \mu \mathrm{M}$ (Table 1). It is worthwhile to mention that under the same experimental conditions known potent antioxidants, trolox ((S)-(-)-6-hydroxy2,5,7,8-tetramethylchromane-2-carboxylic acid) and probucol (4,4'-[(1-methylethylidene)bis(thio)]bis[2,6-bis(1,1dimethylethyl)phenol]), exhibited $\mathrm{IC}_{50}$ values of $25 \mu \mathrm{M}$ and $>1 \mathrm{mM}$, respectively (Kourounakis et al., 2008).
Table $1 \mathrm{IC}_{50}$ values for in vitro lipid peroxidation (LP), LogP, molecular volume $\left(\mathrm{V}_{\mathrm{M}}\right)$, and molecular mass $(\mathrm{M})$ as well as surface area $(\mathrm{S})$ of the tested compounds

\begin{tabular}{lcllll}
\hline Compound & $\mathrm{LP} \mathrm{IC}_{50}(\mu \mathrm{M})$ & $\mathrm{LogP}$ & $\mathrm{M}$ & $\mathrm{S}\left(\AA^{2}\right)$ & $\mathrm{V}_{\mathrm{M}}\left(\AA^{3}\right)$ \\
\hline 3a & 23 & 3.37 & 250.06 & 253.13 & 246.02 \\
3b & 3 & 3.93 & 284.02 & 268.84 & 259.50 \\
$\mathbf{3 c}$ & 2 & 3.25 & 280.07 & 283 & 273.38 \\
$\mathbf{4}$ & 2 & 4.37 & 300.07 & 297.74 & 296.96 \\
$\mathbf{5}$ & 6 & 4.37 & 300.07 & 297.68 & 296.87 \\
$\mathbf{6}$ & 16 & 3.46 & 301.07 & 293.28 & 291.10 \\
$\mathbf{9 a}$ & $>1000$ & 4.20 & 301.07 & 295.91 & 291.54 \\
$\mathbf{9 b}$ & $>1000$ & 6.00 & 395.09 & 374.91 & 379.66 \\
$\mathbf{1 2 a}$ & 1 & 2.71 & 301.07 & 291.11 & 290.87 \\
$\mathbf{1 2 b}$ & 500 & 4.77 & 315.08 & 317.08 & 321.82 \\
$\mathbf{1 2 c}$ & $>1000$ & 4.51 & 395.09 & 359.77 & 375.69 \\
\hline
\end{tabular}

Further, all of the active new derivatives were significantly much more potent than previously studied tricyclic dipyridothiazines $\left(\mathrm{IC}_{50}\right.$ of most active compounds was between 64 and $470 \mu \mathrm{M}$ ) (Morak-Młodawska et al., 2010). The time course of lipid peroxidation, as affected by various concentrations of representative compounds, is depicted in Fig. 1.

Tetracyclic NH-azaphenothiazines 3a-c exhibited significant activity dependent on the substitution $(\mathrm{H}, \mathrm{Cl}$, and $\mathrm{OCH}_{3}$ ) on the benzene ring (Table 1). From the pentacyclic compounds, the angularly fused with unsubstituted, the thiazine nitrogen atom (4-6 and 12a) exhibited very significant activity with most active compound 12a, which showed an $\mathrm{IC}_{50}$ of $1 \mu \mathrm{M}$. The change of the quinoline moiety into naphthalene (compare compounds $\mathbf{4}$ and $\mathbf{5}$ with 

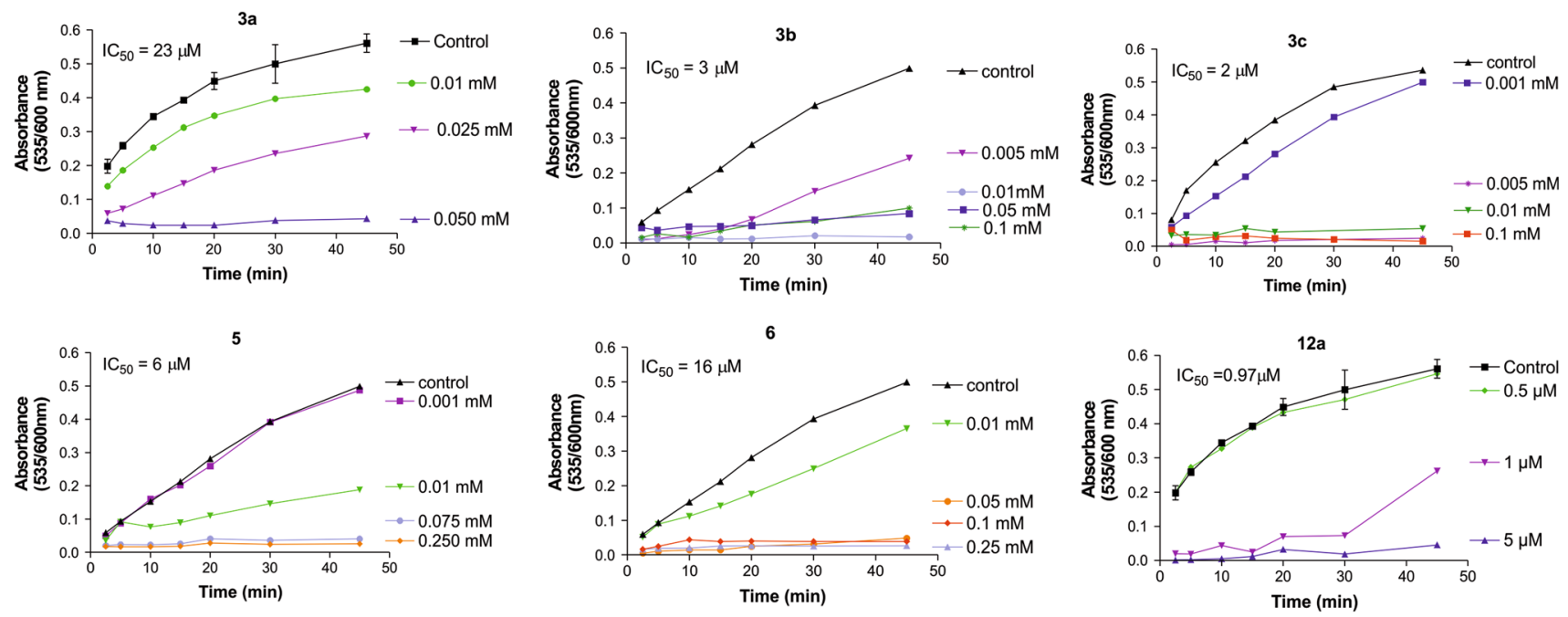

Fig. 1 Representative graphs of the time course of lipid peroxidation as affected by various concentrations of compounds $\mathbf{3 a - c , ~ 5 , ~ 6 , ~ a n d ~}$ 12a. $\mathrm{IC}_{50}$ values are calculated according to these results as the concentration showing $50 \%$ inhibition of the lipid peroxidation reaction at $45 \mathrm{~min}$ incubation time
6) marginally increased activity. However, compounds with a linearly fused ring system (9a and 9b) and/or a large aryl substituent at the thiazine nitrogen atom $(\mathbf{9 b}$ and $\mathbf{1 2 c})$ did not show any antioxidant activity, while compound $\mathbf{1 2 b}$, with a small substituent, exhibited very weak activity.

Considering three isomers $(\mathbf{6}, 9 \mathbf{9}$, and 12a), one can find that their antioxidant activity increased with decreasing lipophilic character represented by the $\log \mathrm{P}$ values. On the other hand, the least active compounds $(\mathbf{9 b}, \mathbf{1 2 b}$, and 12c) exhibited high values of molecular descriptors such as molecular mass $(\mathrm{M}>315)$, molecular volume $\left(V_{\mathrm{M}}>321\right)$, and surface area $(S>317$, Table 1). However, attempts to the correlate the activity with those properties turned out to be unsatisfactory.

In conclusion, eleven tetracyclic and pentacyclic (linearly or angularly condensed) azaphenothiazines were synthesized, and structure-(antioxidant)activity relationships were investigated. The type of the ring fusion was concluded from the ${ }^{1} \mathrm{H}$ NMR spectra. The degree of antioxidant activity of these derivatives seems to depend on their lipophilicity and molecular mass. The non-substitution of the thiazine nitrogen atom, the type of ring system fusion, and the nature of substituents promote activity. Finally, it is the first time to our knowledge that azaphenothiazines are shown to exhibit such potent antioxidant activity.

Acknowledgments The synthesis and the structure elucidation are supported by the Medical University of Silesia (Grant KNW-1-032/K/ $3 / 0$.

Conflict of interest Authors have no financial/commercial conflicts of interest.
Open Access This article is distributed under the terms of the Creative Commons Attribution License which permits any use, distribution, and reproduction in any medium, provided the original author(s) and the source are credited.

\section{References}

Aaron JJ, Gaye Seye MD, Trajkovska S, Motohashi N (2009) Bioactive phenothiazines and benzo[a]phenothiazines: spectroscopic studies and biological and biomedical properties and applications. Top Heterocycl Chem 16:153-231

Asghar MN, Alam Q, Augusten S (2012) Fluphenazine hydrochloride radical cation assay: a new, rapid and precise method to determine in vitro total antioxidant capacity of fruit extracts. Chin Chem Lett 23:1271-1274

Borges MBD, Dos Santos CG, Yokomizo CH, Sood RR, Vitovic PP, Kinnunen KJ, Rodrigues T, Nantes IL (2010) Characterization of hydrophobic interaction and antioxidant properties of the phenothiazine nucleus in mitochondrial and model membranes. Free Radical Res 44:1054-1063

Dasgupta A, Dastridara SG, Shirataki Y, Motohashi Y (2008) Antibacterial activity of artificial phenothiazines and isoflavones from plants. Top Heterocycl Chem 15:67-132

Gupta RR, Kumar M (1988) Synthesis, properties and reactions of phenothiazines. In: Gupta RR (ed) Phenothiazines and 1,4benzothiazines-chemical and biological aspects. Elsevier, Amsterdam, pp 1-161

Hamm P, von Philipsborn W (1971) Protonenresonanzspektren von aromatischen $N$-Oxiden Berechnung der chemischen Verschiebungen, verursacht durch die Feldeffekte der N-O-gruppe. Helv Chim Acta 54:2363-2401

Jeleń M, Pluta K (2009) Synthesis of quinobenzo-1,4-thiazines from diquino-1,4-dithiin and 2,2'-dichloro-3,3'-diquinolinyl disulfide. Heterocycles 78:2325-2336

Jeleń M, Morak-Młodawska B, Pluta K (2011) Thin-layer chromatographic detection of new azaphenothiazines. J Pharm Biomed Anal 55:466-471 
Jeleń M, Pluta K, Zimecki M, Morak-Młodawska B, Artym J, Kocięba M (2013) Synthesis and selected immunological properties of substituted quino[3,2-b]benzo[1,4]thiazines. Eur J Med Chem 63:444-456

Jones G (1977) In: Jones G (ed), The chemistry of heterocyclic compounds, vol 32, Quinolines, Part 1. Wiley, London, p 11-12

Kourounakis AP, Charitos C, Rekka EA, Kourounakis PN (2008) Lipid-lowering (hetero)aromatic tetrahydro-1,4-oxazine derivatives with antioxidant and squalene synthase inhibitory activity. J Med Chem 51:5861-5865

Kumar M, Sharma K, Samarth RM, Kumar A (2010) Synthesis and antioxidant activity of quinobenzothiazinones. Eur J Med Chem 45:4467-4472

Liu Z-Q, Tang Y-Z, Wu D (2009) Antioxidant effects of phenothiazine, phenoxazine, and iminostilbene on free-radical-induced oxidation of linoleic acid and DNA. J Phys Org Chem 22:1009-1014

Lucchini V, Wells PR (1976) Proton magnetic resonance spectra of monosubstituted naphthalenes. Org Magn Reson 8:137-140

Matralis AN, Katselou MG, Nikitakis A, Kourounakis AP (2011) Novel benzoxazine and benzothiazine derivatives as multifunctional antihyperlipidemic agents. J Med Chem 54:5583-5591

Morak-Młodawska B, Pluta K, Matralis AN, Kourounakis AP (2010) Antioxidant activity of newly synthesized 2,7-diazaphenothiazines. Arch Pharm Chem Life Sci 343:268-273

Motohashi N, Kawase M, Satoh K, Sakagami H (2006) Cytotoxic potential of phenothiazines. Curr Drug Targets 7:1055-1066

Naik N, Kumar HV, Veena V (2012) Novel phenothiazine analogous: synthesis and a new perceptivity into their antioxidant potential. Pharmacia Lett 4:786-794

Nowak M, Pluta K, Suwińska K (2002) Synthesis of novel heteropentacenes containing nitrogen, sulfur and oxygen or selenium. New J Chem 26:1216-1220
Nowak M, Pluta K, Kloc K, Siegriest T (2003) Synthesis and X-ray analysis of isomeric diazadithiapentacenes. Heterocycles 60:2045-2056

Nowak M, Pluta K, Suwińska K, Straver L (2007) Synthesis of new pentacyclic diquinothiazines. J Heterocycl Chem 44:543-550

Pluta K (1994) Synthesis and NMR assignment of 1,4-oxathiino[3,2c;5,6-c']diquinoline. J Heterocycl Chem 31:557-560

Pluta K (1997) Synthesis and properties of 14-substituted 1,4thiazinodiquinolines. Phosphorus Sulfur Silicon 126:145-156

Pluta K, Morak-Młodawska B, Jeleń M (2009) Synthesis and properties of diaza-, triaza- and tetraazaphenothiazines. J Heterocycl Chem 46:355-391

Pluta K, Jeleń M, Morak-Młodawska B, Zimecki M, Artym J, Kocięba M (2010) Anticancer activity of newly synthesized azaphenothiazines in NCI's anticancer screening. Pharmacol Rep 62:319-332

Pluta K, Morak-Młodawska B, Jeleń M (2011) Recent progress in biological activities of synthesized phenothiazines. Eur J Med Chem 46:3179-3189

Rekka E, Kolstee J, Timmerman H, Bast A (1989) The effect of some $\mathrm{H}_{2}$-receptor antagonists on rat hepatic microsomal cytochrome P-450 and lipid peroxidation in vitro. Eur J Med Chem 24:43-54

Zhang H-Y, Yang D-P, Tang G-Y (2006) Multipotent antioxidants: from screening to design. Drug Discov Today 11:749-754

Zimecki M, Artym J, Kocięba M, Pluta K, Morak-Młodawska B, Jeleń M (2009) Immunosupressive activities of newly synthesized azaphenothiazines in human and mouse models. Cell $\mathrm{Mol}$ Biol Lett 14:622-635 